\title{
ANALISIS KUALITAS PERAIRAN BERDASARKAN KOMPOSISI DAN KELIMPAHAN FITOPLANKTON DI SUNGAI LANANGAN, KLATEN
}

\author{
Analysis of Water Quality based on Composition and Abundance \\ of Phytoplankton in Lanangan River, Klaten \\ Faudzi Ath Tho Azzam, Niniek Widyorini*), Bambang Sulardiono \\ Program Studi Manajemen Sumberdaya Perairan, Jurusan Perikanan \\ Fakultas Perikanan dan Ilmu Kelautan, Universitas Diponegoro \\ Jl. Prof Soedarto, SH, Tembalang, Semarang, Jawa Tengah - 50275, Telp/Fax. +6224 7474698 \\ Email : Faudziata@gmail.com
}

\begin{abstract}
ABSTRAK
Sungai Lanangan merupakan bagian hulu Sungai Bengawan Solo yang terletak di Desa Daleman, Kecamatan Tulung, Kabupaten Klaten. Jenis limbah seperti limbah domestik, industri, pertanian, perikanan dan peternakan telah mencemari Sungai Lanangan. Limbah organik dari industri tepung aren dan mie soun yang dibuang di Sungai Lanangan mencapai 50 ton limbah per hari. Hal tersebut menyebabkan perubahan kualitas air dan komposisi fitoplankton di Sungai Lanangan.Penelitian ini dilakukan dari bulan Januari - Februari 2018 di Sungai Lanangan. Tujuan dari penelitian ini adalah untuk mengetahui kelimpahan dan komposisifitoplankton serta mengetahui kualitas perairan berdasarkan struktur komunitas fitoplankton di Sungai Lanangan tersebut. Penelitian ini menggunakan metode survei denganpengambilan sampel menggunakan metode purposive sampling. Frekuensi pengambilan sampel dilakukan setiap 1 minggu sekali selama 3 minggu. Sampel diambil dari 3 stasiun, dimana stasiun 1 dengan karakteristik perairan terbuka; Stasiun 2 dengan karakteristik dekat industri pengolahan tepung aren; dan stasiun 3 dengan karakteristik dekat dengan daerah budidaya air tawar.Hasil penelitian didapatkan 11 genera fitoplankton yaitu dari kelas Bacillariophyceae (4 genera), Cyanophyceae (2 genera), Chrysophyceae (1 genus), Ulvophyceae (2 genera), Zygnematophyceae (1 genus) dan Chlorophyceae (1 genus). Kelimpahan rata-rata fitoplankton tertinggi terdapat pada stasiun 2 dengan kelimpahan 1.989 ind/l yang didominasi oleh genus Oscillatoria. Indeks keanekaragaman rata-rata pada setiap stasiun adalah 1,68 pada stasiun 1; 1,63 pada stasiun 2; dan 1,52 pada stasiun 3. Dari hasil indeks keanekaragaman yang didapatkan tersebut menunjukkan kisaran nilai antara 1,52 hingga 1,68 yang berarti bahwa kualitas perairan Sungai Lanangan tercemar ringan.
\end{abstract}

Kata Kunci: Sungai Lanangan; Kualitas Air; Kelimpahan dan Komposisi Fitoplankton

\begin{abstract}
Lanangan river is one upstream of Bengawan Solo river which located at Daleman, Tulung, Klaten. types of waste such as domestic waste, industrial waste, agriculture, fishery and animal husbandry polluted Lanangan river. Especially organic waste from palm starch and soun noodle industry that are dumped in the Lanangan river reaches 50 tonnes waste per day. This research was conducted from January to February 2018 in the Lanangan river. The purpose of this research is to find out the abundance and composition of phytoplankton; and to determine the water qualitybased on the structure of the phytoplankton community in Lanangan river. This research uses survey method and use purposive sampling method. The Frequency of sampling is done once a week for 3 week. The samples taken from 3 stations, where station 1 is open water; Station 2 is near palm starch and soun noodle industry; and station 3 is close to freshwater aquaculture area.The resultsof the research found 11 genus of phytoplankton in class Bacillariophyceae, Cyanophyceae, Chrysophyceae, Ulvophyceae, Zygnematophyceae and Chlorophyceae. The highest average of phytoplankton abundance found in station 2 with 1,989 ind/l which is dominated by the genus of Oscillatoria. The average diversity index each station is 1.68 at station 1; 1.63 at station 2; and 1.52 at station 3. From the results obtained the diversity index indicates the range of values between 1.52 to 1.68 which show that the water quality of Lanangan River is lightly to moderate polluted.
\end{abstract}

Keywords:Lanangan River; Water Quality; Abundance and Composition of Phytoplankton

*) Penulis penanggungjawab 


\section{PENDAHULUAN}

Sungai Lanangan merupakan salah satu hulu dari sungai Bengawan Solo yang terletak di Desa Daleman, Kecamatan Tulung, Kabupaten Klaten, Provinsi Jawa Tengah. Sungai Lanangan memiliki banyak fungsi, diantaranya adalah sebagai habitat dan ekosistem berbagai jenis ikan air tawar, termasuk juga Labi-labi. Selain itu, Sungai lanangan juga berfungsi untuk berbagai aktivitas masyarakat sekitarnya, baik untuk keperluan MCK, tempat memancing, kegiatan budidaya, kegiatan pertanian, kegiatan peternakan dan lainnya (Wibowo et al., 2014).

Limbah kegiatan industri tepung aren dan mie soun yang terdapat pada bantaran sungai Lanangan sangat berpotensi menurunkan kualitas perairan tersebut. Limbah organik dalam bentuk cair maupun padat yang dibuang mencapai 50 ton per hari. Pembuangan limbah yang dilakukan tanpa melalui proses pengolahan terlebih dahulu (Trisnastuti, 2012).

Degradasi kualitas air dapat diakibatkan karena banyaknya pembuangan limbah. Baik limbah industri, pertanian, perikanan serta limbah domestik. Untuk menentukan kualitas air di sungai Lanangan, diperlukan studi analisis biologi dengan menggunakan struktur komunitas fitoplankton yang meliputi komposisi, kelimpahan dan keanekaragaman sebagai bioindikator(Rudiyanti, 2009; Cokrowati, 2014).

Tujuan dari penelitian ini adalah untuk Mengetahui kelimpahan dan komposisi fitoplankton; serta untuk mengetahui kualitas perairan di sungai Lanangan tersebut berdasarkan struktur komunitasnya.

\section{MATERI DAN METODE PENELITIAN}

\section{A. Materi Penelitian}

Penelitian ini dilaksanakan pada bulan Januari - Februari 2018 di perairan sungai Lanangan, Klaten; Laboratorium Balai Perbenihan dan Budidaya Ikan Air Tawar (BPBIAT) Janti; dan Laboratorium Pengelolaan Sumberdaya Ikan dan Lingkungan, Departemen Sumberdaya Akuatik, Fakultas Perikanan dan Ilmu Kelautan, Universitas Diponegoro, Semarang. Materi yang digunakan dalam penelitian ini terdiri dari alat dan bahan yang digunakan untuk pengambilan sampel di lapangan dan alat untuk identifikasi fitoplankton. Alat yang digunakan untuk pengambilan sampel meliputi Plankton Net ukuran $25 \mu \mathrm{m}$ untuk menyaring fitoplankton; Bucket untuk wadah sampel pada plankton net; Ember berskala 10 liter untuk mengambil air sampel fitoplankton; Botol sampel $50 \mathrm{ml}$ untuk wadah fitoplankton; Kertas label memberi label botol sampel fitoplankton; DO meter merk Lutron ketelitian 0,1 mg/l untuk mengukur kadar oksigen terlarut dalam air; Thermometer air raksa ketelitian $1{ }^{\circ} \mathrm{C}$ untuk mengukur temperature air dan udara; Secchi disk modifikasi ketelitian $1 \mathrm{~cm}$ untuk mengukur nilai kecerahan dan kedalaman; Bola arus untuk mengukur kecepatan arus; $p H$ paper merk Merck untuk mengukur nilai $\mathrm{pH}$ air; Pipet tetes untuk pemipetan reagen dalam sampel fitoplankton; Kamera untuk dokumentasi penelitian; cool box sebagai tempat penyimpanan sementara botol sampel air; Alat tulis untuk mencatat hasil. Alat yang digunakan untuk identifikasi fitoplankton meliputi Mikroskop merk Olympus untuk mengamati sampel fitoplankton; Sedgwick-Rafter digunakan sebagai alat pencacah fitoplankton; Cover glass untuk menutup alat pencacah fitoplankton; Pipet tetes untuk mengambil air sampel fitoplankton; Form identifikasi fitoplankton dan alat tulis untuk mencatat hasil dari identifikasi fitoplankton; Buku identifikasi plankton Sachlan (1982) untuk identifikasi fitoplankton.

\section{B. Metode Penelitian}

Metode yang digunakan dalam penelitian adalah survei, yaitu metode penelitian dimana data yang diambil dari sampel atau populasi digunakan untuk mewakili seluruh populasi. Pengambilan sampel dilakukan dengan metode purposive sampling, yaitu penentuan lokasi yang didasarkan atas adanya tujuan tertentu dan sesuai dengan pertimbangan peneliti sendiri sehingga mewakili populasi (Arikunto, 2006).

Lokasi pengambilan sampel dipilih 3 stasiun dimana masing-masing stasiun diharapkan dapat mewakili kondisi perairan. Stasiun I terletak di daerah dengan karakteristik persawahan; Stasiun II terletak di daerah dengan karakteristik dekat industri pengolahan tepung aren; Stasiun III terletak di daerah dengan karakteristik dekat dengan lingkungan budidaya ikan air tawar dan aktivitas antropogenik rumah tangga.

\section{Analisis Data}

\section{Kelimpahan Fitoplankton (N)}

Perhitungan kelimpahan fitoplankton, menggunakan rumus APHA (2005) dalam Ardiansyah (2017).

\section{Analisa Indeks Keanekaragaman (H')}

Indeks keanekaragaman merupakan indeks yang mengilustrasikan struktur komunitas kehidupan yang dapat mempermudah menganalisis informasi-informasi tentang jumlah dan macam organisme (Odum, 1993). Adapun indeks keanekaragaman (H') dihitung dengan rumus Shanon-Wiener dalam Kamilah et al. (2014) sebagai berikut:

$$
\mathrm{H}^{\prime}=-\sum_{\mathrm{i}=1}^{\mathrm{S}} \mathrm{Pi} \ln \mathrm{Pi}
$$

Keterangan :

H' = Indeks Keanekaragaman

$\mathrm{S} \quad=$ Banyaknya Spesies

$\mathrm{Pi} \quad=$ Jumlah individu jenis ke-i dibagi dengan jumlah individu total 


\section{Analisa Indeks Keseragaman (e)}

Indeks keseragaman digunakan untuk mengetahui penyebaran individu tiap genus yang mendominasi suatu populasi. Indeks keseragaman berdasarkan persamaan Odum (1993) adalah sebagai berikut:

$$
\mathrm{e}=\frac{H^{\prime}}{\operatorname{Ln} S}
$$

Keterangan :

$$
\begin{aligned}
& \text { e = indeks keseragaman } \\
& \text { H' = indeks keanekaragaman } \\
& \mathrm{S} \quad=\text { jumlah jenis }
\end{aligned}
$$

\section{Analisa Indeks Dominansi (C)}

Indeks dominansi digunakan untuk melihat dominasi oleh jenis tertentu pada populasi fitoplankton dengan menggunakan Indeks Dominansi Simpson (Odum, 1993). dengan rumus sebagai berikut:

Keterangan :

$$
\mathrm{C}=\Sigma\left(\mathrm{n}_{i} / \mathrm{N}\right)^{2}
$$

$$
\begin{array}{ll}
\mathrm{C} & =\text { indeks dominansi } \\
\mathrm{n}_{\mathrm{i}} & =\text { jumlah individu jenis ke-i } \\
\mathrm{N} & =\text { jumlah total individu }
\end{array}
$$

\section{HASIL DAN PEMBAHASAN}

\section{Gambaran umum lokasi penelitian}

Sungai Lanangan merupakan salah satu hulu dari sungai Bengawan Solo yang terletak di Dukuh Bendo, Desa Daleman, Kecamatan Tulung, Kabupaten Klaten, Provinsi Jawa Tengah. Sungai Lanangan ini berada pada dataran tinggi tepatnya di sebelah timur Gunung Merapi dengan karakteristik khas sungai hulu yang curam, lurus, berarus deras dan berbatu.

Stasiun I terletak di koordinat $7^{\circ} 35^{\prime} 09.06^{\prime}$ "LS $110^{\circ} 37^{\prime} 08.95$ 'BT, lokasi ini merupakan perairan terbuka dengan dikelilingi oleh daerah persawahan yang cukup luas. Stasiun II terletak di koordinat $7^{\circ} 35^{\prime} 24.37^{\prime}$ ' LS $110^{\circ}$ 37'50.58" BT, lokasi ini dekat dengan kawasan industri dan pemukiman penduduk yang cukup padat. Stasiun III terletak di koordinat $7^{\circ} 35^{\prime} 31.37^{\prime}$ LS $110^{\circ} 38^{\prime} 06.86^{\prime}$ BT, lokasi ini merupakan outlet dari kawasan industri dan kawasan budidaya ikan air tawar. Peta lokasi dapat dilihat pada gambar 1.

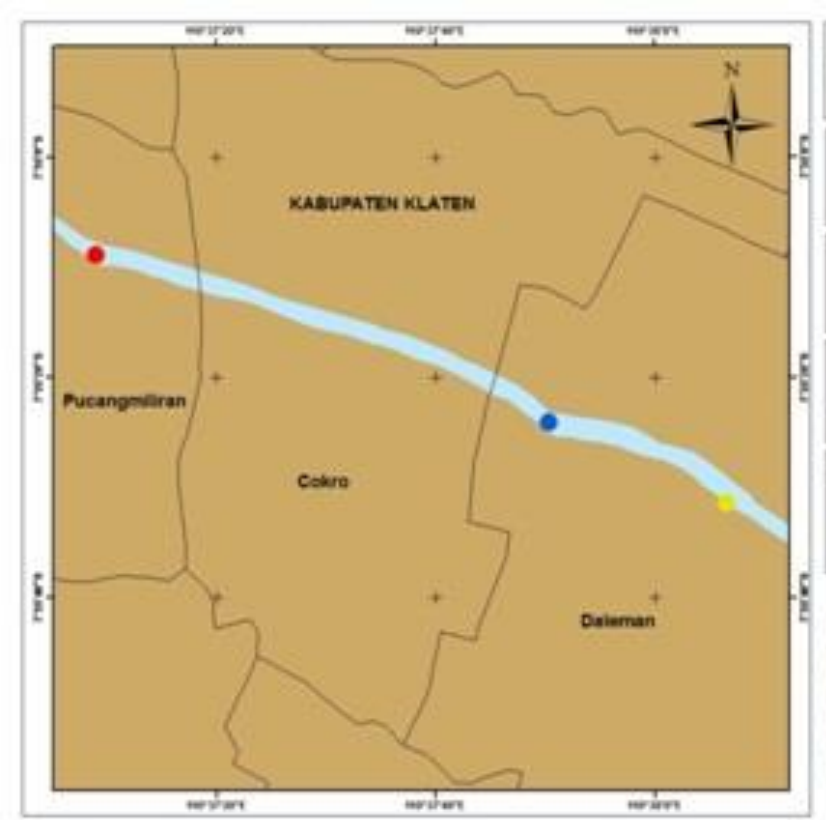

Gambar 1. Peta Lokasi

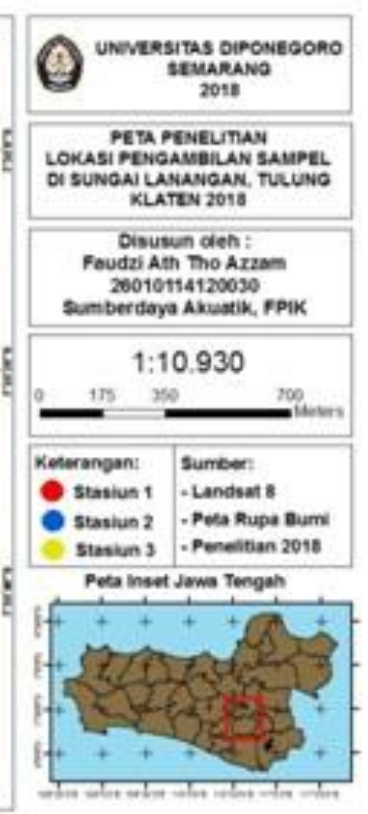

\section{Komunitas plankton}

Kelimpahan fitoplankton yang diperoleh dari penelitian di sungai Lanangan, terdiri atas 6 kelas dan 11 genera yaitu Bacillariophyceae (4 genera), Cyanophyceae (2 genera), Chrysophyceae (1 genera), Ulvophyceae (2 genera), 
Zygnematophyceae (1 genera) dan Chlorophyceae (1 genera). Hasil kelimpahan fitoplankton di setiap stasiun disajikan pada tabel 1.

Tabel 1. Kelimpahan Fitoplankton di Sungai Lanangan (ind/L)

\begin{tabular}{|c|c|c|c|c|c|c|c|c|c|c|c|c|c|}
\hline \multirow{3}{*}{ No } & \multirow{3}{*}{ Genus } & \multicolumn{4}{|c|}{ Stasiun A } & \multicolumn{3}{|c|}{ Stasiun B } & \multicolumn{5}{|c|}{ Stasiun C } \\
\hline & & \multicolumn{3}{|c|}{ Minggu } & \multirow[t]{2}{*}{ Total } & \multicolumn{3}{|c|}{ Minggu } & \multirow[t]{2}{*}{ Total } & \multicolumn{3}{|c|}{ Minggu } & \multirow[t]{2}{*}{ Tota } \\
\hline & & 1 & 2 & 3 & & 1 & 2 & 3 & & 1 & 2 & 3 & \\
\hline & Baccillariophyceae & & & & & & & & & & & & \\
\hline 1 & Navicula & 500 & 567 & 150 & 1217 & 617 & 100 & 83 & 800 & 113 & 150 & 0 & 263 \\
\hline 2 & Nitzschia & 100 & 0 & 0 & 100 & 0 & 0 & 0 & 0 & 17 & 17 & 0 & 34 \\
\hline 3 & fragilaria & 0 & 50 & 0 & 50 & 0 & 83 & 0 & 83 & 0 & 0 & 0 & 0 \\
\hline \multirow[t]{2}{*}{4} & Hantzschia & 0 & 183 & 0 & 183 & 0 & 0 & 0 & 0 & 0 & 50 & 0 & 50 \\
\hline & Cyanophyceae & & & & & & & & & & & & \\
\hline 5 & Gomphosphaeria & 433 & 550 & 300 & 1283 & 250 & 150 & 267 & 667 & 450 & 100 & 33 & 583 \\
\hline \multirow[t]{2}{*}{6} & Oscillatoria & 367 & 550 & 67 & 984 & 667 & 683 & 83 & 1433 & 100 & 217 & 117 & 434 \\
\hline & Chrysophyceae & & & & & & & & & & & & \\
\hline \multirow[t]{2}{*}{7} & Crysococcus & 200 & 367 & 250 & 817 & 317 & 400 & 167 & 884 & 0 & 550 & 550 & 1100 \\
\hline & Ulvophyceae & & & & & & & & & & & & \\
\hline 8 & Cladophora & 0 & 0 & 0 & 0 & 33 & 33 & 400 & 466 & 50 & 517 & 267 & 834 \\
\hline \multirow[t]{2}{*}{9} & Ulothrix & 0 & 133 & 17 & 150 & 117 & 1000 & 100 & 1217 & 67 & 417 & 217 & 701 \\
\hline & Zygnematophyceae & & & & & & & & & & & & \\
\hline \multirow[t]{2}{*}{10} & Closterium & 0 & 0 & 33 & 33 & 0 & 0 & 0 & 0 & 0 & 0 & 0 & 0 \\
\hline & Chlorophyceae & & & & & & & & & & & & \\
\hline \multirow[t]{2}{*}{11} & Eudorina & 267 & 250 & 0 & 517 & 50 & 367 & 0 & 417 & 0 & 433 & 0 & 433 \\
\hline & Total & & & & 5334 & & & & 5967 & & & & 4432 \\
\hline
\end{tabular}

Berdasarkan tabel diatas, Genera dengan rata-rata kelimpahan tertinggi adalah Navicula, Gomposphaeria, Crysococcus dan Ulothrix. Empat genera tersebut termasuk kedalam kelas Bacillariophyceae, Cyanophyceae, Chrysophyceae dan Ulvophyceae.Kelimpahan fitoplankton rata-rata pada minggu pertama berkisar antara 817 - 2050 ind/l. Pada minggu kedua berkisar antara $2.450-2.817$ ind/l. Sedangkan pada minggu ketiga kelimpahan fitoplankton berkisar antara 817 - 1183 ind/l. Rata-rata kelimpahan fitoplankton stasiun B merupakan kelimpahan tertinggi, dengan nilai rata-rata $1.989 \mathrm{ind} / \mathrm{l}$. Stasiun yang memiliki nilai rata-rata kelimpahan fitoplankton terendah adalah stasiun $\mathrm{C}$ dengan nilai rata-rata sebesar $1.483 \mathrm{ind} / \mathrm{l}$.

Hasil perhitungan indeks keanekaragaman fitoplankton masing-masing stasiun disajikan pada Tabel 2.

Tabel 2. Indeks Keanekaragaman Fitoplankton

\begin{tabular}{cccc}
\hline \multirow{2}{*}{ Minggu } & \multicolumn{3}{c}{ Nilai Rata-rata Indeks Keanekaragaman } \\
\cline { 2 - 4 } & Stasiun A & Stasiun B & Stasiun C \\
\hline 1 & 1,69 & 1,59 & 1,34 \\
2 & 1,89 & 1,69 & 1,90 \\
3 & 1,47 & 1,61 & 1,33 \\
Rata-rata & 1,68 & 1,63 & 1,52 \\
\hline
\end{tabular}

Berdasarkan tabel diatas, Nilai rata-rata indeks keanekaragaman tertinggi terdapat pada stasiun A dengan nilai rata-rata sebesar 1,68. Sedangkan nilai rata-rata indeks keanekaragaman terendah terdapat pada stasiun $\mathrm{C}$ dengan nilai rata-rata sebesar 1,52 .

Hasil perhitungan indeks keseragaman fitoplankton masing-masing stasiun disajikan pada Tabel 3.

Tabel 3. Indeks Keseragaman Fitoplankton

\begin{tabular}{cccc}
\hline \multirow{2}{*}{ Minggu } & \multicolumn{3}{c}{ Nilai Rata-rata Indeks Keseragaman } \\
\cline { 2 - 4 } & Stasiun A & Stasiun B & Stasiun C \\
\hline 1 & 0,94 & 0,82 & 0,75 \\
2 & 0,91 & 0,81 & 0,87 \\
3 & 0,81 & 0,90 & 0,83 \\
Rata-rata & 0,89 & 0,84 & 0,81 \\
\hline
\end{tabular}

${ }^{\odot}$ Copyright by Management of Aquatic Resources (MAQUARES) 
Berdasarkan tabel diatas, nilai rata-rata indeks keseragaman tertinggi terdapat pada stasiun A dengan nilai ratarata sebesar 0,89 . Sedangkan nilai rata-rata indeks keseragaman terendah terdapat pada stasiun $\mathrm{C}$ dengan nilai rata-rata sebesar 0,81 .

Hasil perhitungan indeks dominansi fitoplankton masing-masing stasiun disajikan pada Tabel 4.

Tabel 4. Indeks Dominansi Fitoplankton

\begin{tabular}{cccc}
\hline \multirow{2}{*}{ Minggu } & \multicolumn{3}{c}{ Nilai Rata-rata Indeks Dominansi } \\
\cline { 2 - 4 } & Stasiun A & Stasiun B & Stasiun C \\
\hline 1 & 0,20 & 0,24 & 0,36 \\
2 & 0,17 & 0,23 & 0,17 \\
3 & 0,27 & 0,23 & 0,31 \\
Rata-rata & 0,21 & 0,23 & 0,28
\end{tabular}

Berdasarkan tabel diatas, nilai rata-rata indeks dominansi tertinggi terjadi pada stasiun $\mathrm{C}$ dengan nilai rata-rata sebesar 0,28. Sedangkan nilai rata-rata indeks dominansi terendah terjadi pada stasiun A dengan nilai rata-rata sebesar 0,21 .

\section{Parameter kualitas air pendukung}

Hasil pengukuran parameter fisika-kimia pada masing-masing stasiun di sungai Lanangan, Klaten didapatkan rata-rata kualitas air seperti yang tersaji dalam tabel 5.

Tabel 5. Pengukuran Parameter Fisika-Kimia

\begin{tabular}{lccccccccc}
\hline & \multicolumn{3}{c}{ Stasiun A } & \multicolumn{3}{c}{ Stasiun B } & \multicolumn{3}{c}{ Stasiun C } \\
\cline { 2 - 11 } Variabel & \multicolumn{3}{c}{ Minggu } & \multicolumn{3}{c}{ Minggu } & \multicolumn{3}{c}{ Minggu } \\
\cline { 2 - 10 } & 0,20 & 0,33 & 0,11 & 0,33 & 0,50 & 0,25 & 0,17 & 0,50 & 0,20 \\
\hline Arus (m/s) & 0,38 & 0,22 & 0,32 & 0,52 & 0,35 & 0,29 & 0,42 & 0,35 & 0,32 \\
Kecerahan (m) & 0,52 & 0,62 & 0,68 & 0,61 & 0,75 & 0,57 & 0,42 & 0,6 & 0,41 \\
Kedalaman (m) & 26 & 25 & 25 & 27 & 24 & 25 & 27 & 25 & 25 \\
Temperatur Air $\left({ }^{\circ} \mathrm{C}\right)$ & 31 & 24 & 27 & 32 & 25 & 27 & 29 & 27 & 27 \\
Temperatur Udara $\left({ }^{\circ} \mathrm{C}\right)$ & 2,1 & 2,3 & 2,5 & 1,6 & 2,1 & 2,2 & 1,1 & 1,8 & 2,1 \\
DO(mg/l) & 7 & 7 & 7 & 7 & 7 & 7 & 7 & 7 & 7 \\
pH & 3,425 & 4,072 & 3,279 & 2,969 & 3,728 & 4,693 & 2,417 & 5,521 & 4,728 \\
Nitrat (mg/l) & 0,299 & 1,476 & 0,425 & 0,538 & 2,677 & 0,754 & 0,405 & 0,876 & 0,554 \\
Fosfat (mg/l) & & & & & & & & & \\
\hline
\end{tabular}

\section{Pembahasan}

\section{Komunitas plankton}

Berdasarkan hasil identifikasi dan perhitungan kelimpahan fitoplankton yang didapatkan dari tiga stasiun, diketahui bahwa terdapat 6 kelas dan 11 genera. Kelimpahan rata-rata meningkat pada minggu kedua, diduga karena pada saat minggu kedua dilakukan terjadi hujan dan meningkatnya debit air sungai. Sehingga memengaruhi arus air, kedalaman, pengadukan sedimen, kecerahan, distribusi zat hara serta fitoplankton. Hal ini diperkuat oleh Rigitta $e t$ al. (2015), bahwa sumber, kecepatan serta arah arus memengaruhi distribusi dari zat hara pada perairan. Selain zat hara, arus air juga memengaruhi pengadukan sedimen serta distribusi fitoplankton.

Genera yang sering ditemukan dan dengan rata-rata kelimpahan tertinggi adalah Navicula, Gomposphaeria, Crysococcus dan Ulothrix. Empat genera tersebut termasuk kedalam kelas Bacillariophyceae, Cyanophyceae, Chrysophyceae dan Ulvophyceae. Menurut Durocher et al. (2015); Kamilah et al. (2014); Sagala (2013), jenis-jenis yang didapatkan tersebut memang jenis fitoplankton yang sering ditemui di perairan tawar, khususnya sungai. Seperti Ulothrix, Navicula, Closteriun dan lainnya.

Menurut Khasanah et al. (2013), kelas diatom (Bacillariophyceae) merupakan kelas yang sering ditemukan pada perairan darat hingga laut. Diperkuat oleh Odum (1993), bahwa kelas Bacillariophyceae bersifat kosmopolitan, yaitu memiliki kemampuan toleransi dan adaptasi yang tinggi terhadap berbagai macam kondisi lingkungan. Hal ini juga diperkuat oleh Nybakken (1992); Kamilah et al. (2014); Sagala (2013), bahwa kelas Bacillariophyceae atau diatom, Cyanophyceae, dan Chlorophyceae merupakan fitoplankton yang umum ditemukan pada perairan sungai Indonesia. Khususnya kelas Bacillariophyceae, masih mampu tumbuh dengan baik ketika berada pada perairan dengan kondisi cahaya dan nutrien yang rendah. Kelas Bacillariophyceae ini juga memiliki kemampuan beradaptasi yang sangat baik sehingga mampu beregenerasi dan bereproduksi dalam jumlah yang lebih besar dari jenis fitoplankton lain. Sehingga seringkali ditemukan mendominasi suatu perairan. 
Rata-rata kelimpahan fitoplankton Stasiun B merupakan yang tertinggi, dengan nilai rata-rata 1.989 ind/l. Sedangkan Stasiun C kelimpahan rata-rata fitoplanktonnya merupakan yang terendah dengan nilai rata-rata sebesar 1.483 ind/l. Kelimpahan yang menurun pada Stasiun C diduga disebabkan oleh beberapa faktor, diantaranya terlalu banyak kandungan nitrat dan fosfat serta variabel lain yang tidak mendukung seperti oksigen terlarut yang lebih sedikit. Menurut Anwar (2014), pertumbuhan fitoplankton bergantung pada fluktuasi unsur hara serta proses hidrodinamika yang terdapat pada perairan. Kondisi perairan juga akan memengaruhi distribusi fitoplankton baik secara horizontal maupun vertikal. Sedangkan kelimpahan fitoplankton di suatu perairan dapat dipengaruhi parameter lingkungan dan karakteristik fisiologisnya.

Nilai indeks keanekaragaman rata-rata stasiun A, B dan C yaitu 1,68; 1,63 dan 1,52. Hal tersebut menunjukkan bahwa keanekaragaman dan penyebaran jumlah individu setiap jenis fitoplankton, kestabilan komunitas fitoplankton sedang dan mulai mengalami penurunan nilai indeks keanekaragaman dari Stasiun A hingga stasiun C. Menurut Usman et al. (2013); Haq et al. (2015), keanekaragaman, penyebaran jumlah individu setiap jenis dan kestabilan komunitas fitoplankton dikatakan sedang apabila nilai indeks keanekaragaman berkisar antara 1 - 3. Keanekaragaman rendah apabila nilai indeks keanekaragamannya kurang dari 1 dan tinggi apabila lebih dari 3. Penurunan nilai indeks keanekaragaman yang terjadi diduga karena pada stasiun B dan $\mathrm{C}$ terdapat banyak limbah industri pengolahan tepung aren dan mie soun, sehingga dapat memengaruhi kelimpahan dan komposisi fitoplankton di sungai tersebut.Nilai indeks keanekaragaman yang diperoleh menunjukkan bahwa Sungai Lanangan tercemar ringan hingga sedang. Menurut Soegianto (2010), indeks keanekaragaman dengan kisaran 1,60 - 2,00 termasuk dalam kategori perairan yang tercemar ringan, dan indeks keanekaragaman dengan kisaran 1,00 - 1,59 termasuk dalam kategori perairan yang tercemar sedang.

Nilai indeks keseragaman rata-rata tertinggi terdapat pada Stasiun A dengan nilai 0,89. Sedangkan nilai indeks keseragaman rata-rata terendah terdapat pada Stasiun C dengan nilai 0,81. Nilai indeks keseragaman rata-rata pada setiap stasiun menunjukkan bahwa sebaran individu antar jenis merata, akan tetapi mulai terlihat sebaran individu yang kurang merata serta mulai terjadi terjadi dominasi berdasarkan nilai indeks keseragaman yang menurun dari stasiun A hingga stasiun C.Genus yang banyak ditemukan adalah genus Bacillariophyceae, Chrysophyceae dan Cyanophyceae. Menurut Haq et al. (2015), nilai indeks keseragaman mendekati atau sama dengan 0, menunjukkan bahwa penyebaran antar jenis tidak merata dan terdapat kecenderungan bahwa suatu jenis mendominasi perairan tersebut, sebaliknya jika nilai indeks keseragaman yang mendekati atau sama dengan 1, menunjukkan bahwa penyebaran antar jenis merata dan tidak terdapat kecenderungan bahwa suatu jenis mendominasi perairan tersebut.

Nilai indeks dominansi rata-rata yang terdapat pada Stasiun A, B dan Cadalah 0,21; 0,23 dan 0,28. Hal tersebut menunjukkan bahwa hampir tidak ada jenis yang mendominasi dan mulai terjadi peningkatan nilai indeks dominansi dari Stasiun A hingga Stasiun C. Yuliana (2015) bahwa nilai indeks dominansi fitoplankton yang mendekati atau sama dengan 0 berarti bahwa tidak ada jenis fitoplankton yang mendominasi, namun apabila indeks dominansi mendekati atau sama dengan 1 berarti terdapat jenis fitoplankton yang mendominasi. Menurut Anwar et al. (2014), perairan yang tercemar oleh limbah organik maupun anorganik, secara tidak langsung menjadi salah satu faktor kurangnya keanekaragaman spesies pada perairan tersebut dan kemudian menunjukkan nilai dominansi yang tinggi.

Penurunan nila indeks keanekaragaman, penurunan nilai indeks keseragaman serta naiknya nilai indeks dominansi dari Stasiun A hingga C ini diduga dipengaruhi oleh kualitas air yang berubah, seperti menurunnya kandungan oksigen terlarut serta naiknya kandungan nitrat dari stasiun A hingga stasiun C. Hal tersebut juga mengakibatkan keanekaragaman semakin berkurang, jenis-jenis yang didapatkan semakin seragam serta dominansi dari jenis tertentumeningkat, seperti kelasUlvophyceae dan Chrysophyceae yang kelimpahannya meningkat pada stasiun B dan C, serta kelas lain seperti Bacillariophyceae dan Zygnematophyceae yang kelimpahannya menurun pada stasiun B dan C. Menurut Durocher et al. (2015); Kamilah et al. (2014); Sagala (2013), jenis-jenis yang didapatkan tersebut memang jenis fitoplankton yang sering ditemui di perairan tawar, khususnya sungai. Seperti Ulothrix, Navicula, Closterium dan Oscillatoria. Diperkuat oleh Odum (1993), bahwa kelas-kelas yang didapatkan tersebut, khususnya Bacillariophyceae bersifat kosmopolitan, yaitu memiliki kemampuan toleransi dan adaptasi yang tinggi terhadap berbagai macam kondisi lingkungan perairan.

\section{Parameter fisika-kimia perairan}

Hasil pengukuran kecepatan arus pada minggu pertama berkisar antara $0,17-0,33 \mathrm{~m} / \mathrm{s}$. pada minggu kedua kecepatan arus berkisar antara 0,33 - 0,50 m/s. sedangkan pada minggu ketiga, kecepatan arus berkisar antara 0,11 $0,25 \mathrm{~m} / \mathrm{s}$. Nilai kecepatan arus rata-rata paling rendah berada pada stasiun A, dengan nilai rata-rata $0,2 \mathrm{~m} / \mathrm{s}$. Sedangkan nilai kecepatan arus rata-rata paling tinggi berada pada stasiun $\mathrm{B}$, dengan nilai rata-rata $0,4 \mathrm{~m} / \mathrm{s}$. Berdasarkan hasil tersebut, kecepatan arus di Sungai Lanangan dapat dikategorikan sebagai Sungai berkecepatan arus sedang karena kecepatan arusnya berkisar antara 0,25 - 0,5 m/s. Hal ini diperkuat oleh Mason (1981) dalam Sumartini (2013), bahwa klasifikasi sungai berdasarkan kecepatan arus ada 5 macam, yaitu sungai arus sangat deras $(>1 \mathrm{~m} / \mathrm{s})$, sungai arus deras $(0,5-1 \mathrm{~m} / \mathrm{s})$, sungai arus sedang $(0,25-0,5 \mathrm{~m} / \mathrm{s})$, sungai arus lambat $(0,1-0,25 \mathrm{~m} / \mathrm{s})$ dan sungai arus sangat lambat $(<0,1$ $\mathrm{m} / \mathrm{s}$ ). Perbedaan kecepatan arus pada Sungai Lanangan diduga karena beberapa faktor, diantaranya adalah kemiringan penampang yang berbeda, lebar sungai, hambatan aliran, dan lainnya. Hal ini diperkuat oleh Adinugroho et al. (2014), arus atau kecepatan arus merupakan suatu parameter fisika yang mempunyai peranan penting dalam penelitian terkait badan perairan. Arus merupakan suatu massa air yang bergerak. Pergerakan ini dapat diakibatkan oleh adanya kekuatan angin di atas permukaan perairan, kemiringan tanah, perbedaan densitas dan lainnya. Kecepatan arus dapat digunakan 
sebagai penentuan pola nutrien yang ada di perairan sebagai indikator distribusi plankton (fitoplankton). Fitoplankton sendiri mempunyai sifat melayang-layang mengikuti arus, maka dari itu pola persebaran fitoplankton sangat dipengaruhi oleh pola arus yang ada. Kecepatan arus yang didapat termasuk kecepatan arus yang tinggi dan dapat memengaruhi distribusi fitoplankton, difusi oksigen, distribusi limbah dan lainnya. Diperkuat oleh Handoko et al. (2013), bahwa pola arus yang terjadi dapat mendominasi arah sebaran $\mathrm{pH}$, fitoplankton, nutrien dan zat lainnya yang ada pada perairan. Diperkuat oleh Anwar (2014), bahwa kecepatan arus memengaruhi kelimpahan fitoplankton yang ada pada suatu perairan.

Hasil pengukuran kecerahan pada minggu pertama berksiar antara 0,38 - 0,52 m. Pada minggu kedua kecerahan berkisar antara 0,22 - 0,35 $\mathrm{m}$. Sedangkan pada minggu ketiga, kecerahan berkisar antara 0,29-0,32 m. Nilai kecerahan paling rendah berada pada stasiun A dan $\mathrm{C}$ dengan nilai $0,3 \mathrm{~m}$. Sedangkan nilai kecerahan paling tinggi berada pada stasiun B dengan nilai 0,4 m, sehingga pada stasiun B didapatkan kelimpahan fitoplankton yang lebih tinggi, yaitu 5967 ind/l dibandingkan kelimpahan fitoplankton yang berada pada stasiun A dan C dengan 5334 ind/l dan 4432 ind/l. Kecerahan disini sangat berkaitan dengan proses fotosintesis fitoplankton. Semakin tinggi nilai kecerahan, maka semakin banyak intensitas cahaya matahari yang masuk ke dalam badan perairan yang nantinya digunakan fitoplankton sebagai sumber energi dalam proses fotosintesis. Hal ini diperkuat oleh Anwar (2014), bahwa nilai kecerahan yang rendah serta kekeruhan yang tinggi akan mengakibatkan sedikitnya cahaya matahari yang masuk ke dalam perairan. Akibatnya, proses fotosintesis menjadi berkurang, kandungan oksigen menjadi berkurang serta kelimpahan fitoplankton pada perairan tersebut juga akan berkurang. Menurut Sulardiono et al. (2015), terjadi penetrasi cahaya setelah masuk ke badan perairan sebelum digunakan untuk proses fotosintesis. Perbedaan kecerahan yang terjadi ini dapat disebabkan beberapa faktor, diantaranya adalah cuaca, arus padatan tersuspensi, waktu pengukuran dan lainnya. Menurut Rahmawati et al. (2014), nilai kecerahan yang terdapat pada suatu perairan dapat dipengaruhi oleh cuaca, warna perairan, waktu pengukuran, padatan tersuspensi serta ketelitian peneliti.

Hasil pengukuran kedalaman pada minggu pertama berksiar antara 0,42 - 0,61 m. Pada minggu kedua kedalaman berkisar antara 0,60-0,75 $\mathrm{m}$. Sedangkan pada minggu ketiga, kedalaman berkisar antara 0,41 - 0,68 $\mathrm{m}$. Nilai kedalaman rata-rata paling rendah berada pada stasiun $C$, dengan nilai rata-rata $0,5 \mathrm{~m}$. Sedangkan nilai kedalaman rata-rata paling tinggi berada pada stasiun A dan B, dengan nilai rata-rata 0,6 m.Stasiun A dengan kedalaman 0,6 m dan kecepatan arus $0,2 \mathrm{~m} / \mathrm{s}$ memiliki kecerahan paling rendah dengan nilai $0,3 \mathrm{~m}$. Stasiun $\mathrm{B}$ dengan kedalaman $0,6 \mathrm{~m}$ dan kecepatan arus $0,4 \mathrm{~m} / \mathrm{s}$ memiliki kecerahan yang paling tinggi dengan nilai $0,4 \mathrm{~m}$. Stasiun $\mathrm{C}$ dengan kedalaman paling rendah yaitu $0,5 \mathrm{~m}$ dan kecepatan arus $0,3 \mathrm{~m} / \mathrm{s}$ memiliki kecerahan paling rendah dengan nilai $0,3 \mathrm{~m}$.Dari hal tersebut menunjukkan bahwa perairan yang lebih dangkal dan berarus lebih deras cenderung memiliki kecerahan yang rendah, akan tetapi jika substratnya berbeda juga akan memengaruhi nilai kecerahan tersebut, seperti pada stasiun A. Bagian tepi sungai pada stasiun A merupakan tanah liat karena berbatasan langsung dengan persawahansehingga kecerahan pada stasiun ini lebih rendah.Bagian tepi sungai pada stasiun B dan C berbeda, lebih banyak pasir dan batu karena merupakan pemukiman warga dan kawasan industri, sehingga kecerahan perairannya cenderung lebih tinggi. Menurut Sulardiono et al. (2015), umumnya semakin dalam suatu perairan, maka intensitas cahaya matahari yang masuk akan semakin menurun. Akan tetapi, menurut Budiasih et al. (2015), jika kecepatan arus tinggi disertai kedalaman perairan yang dangkal dapat menyebabkan pengadukan sedimen, sehingga partikel-partikel debu yang ada pada sedimen menyebar di perairan mengakibatkan kecerahan menjadi rendah.

Hasil pengukuran temperatur air pada minggu pertama berksiar antara $26-27{ }^{\circ} \mathrm{C}$. pada minggu kedua temperatur air berkisar antara $24-25{ }^{\circ} \mathrm{C}$. sedangkan pada minggu ketiga, temperatur air $25^{\circ} \mathrm{C}$. Nilai temperatur air ratarata paling rendah berada pada stasiun A dan B, dengan nilai rata-rata $25^{\circ} \mathrm{C}$. Sedangkan nilai temperatur air rata-rata paling tinggi berada pada stasiun $\mathrm{C}$, dengan nilai rata-rata $26^{\circ} \mathrm{C}$.Berdasarkan hasil tersebut, temperatur air tidak banyak memengaruhi kelimpahan dan komposisi fitoplankton, karena temperatur yang didapat termasuk temperatur yang baik untuk menunjang kehidupan di perairan terutama bagi fitoplankton. Menurut Effendi (2003), temperatur air optimum yang diperlukan untuk pertumbuhan fitoplankton pada suatu perairan adalah $20-30^{\circ} \mathrm{C}$. Hal ini diperkuat oleh Hutabarat dan Evans (1984) dalam Rahmawati et al. (2014), bahwa fitoplankton dapat tumbuh dan berkembang baik pada temperatur yang berkisar antara $24-32{ }^{\circ} \mathrm{C}$.Semakin tinggi temperatur akan memengaruhi proses metabolisme mahluk hidup yang ada di perairan, menurunkan kelarutan oksigen serta memengaruhi nilai $\mathrm{pH}$ perairan.Menurut Nontji (2008) dalam Khasanah et al. (2013), temperatur dapat memengaruhi proses fotosintesis di suatu perairan baik secara langsung, maupun tak langsung. Pengaruh langsung temperatur terjadi karena temperatur mengendalikan reaksi kimia enzimatik yang berperan dalam proses fotosintesis. Laju fotosintesis akan naik ketika terjadi peningkatan temperatur hingga batas tertentu. Sedangkan pengaruh tak langsung dari temperatur kepada perairan adalah karena struktur hidrologis suatu perairan dimana fitoplankton itu berada akan ditentukan oleh temperatur.

Hasil pengukuran oksigen terlarut pada minggu pertama berkisar antara 1,1-2,1 mg/l. Pada minggu kedua nilai oksigen terlarut berkisar antara 1,8 - 2,3 mg/l. Sedangkan pada minggu ketiga, nilai oksigen terlarut berkisar antara 2,1 $2,5 \mathrm{mg} / \mathrm{l}$. Nilai oksigen terlarut paling rendah berada pada stasiun $\mathrm{C}$ baik pada minggu pertama, kedua maupun ketiga. Sedangkan nilai oksigen terlarut paling tinggi berada pada stasiun A baik pada minggu pertama, kedua maupun ketiga. Nilai oksigen terlarut yang didapatkan tersebut termasuk nilai yang kurang baik bagi perairan, penurunan oksigen terlarut yang terjadi dari stasiun A hingga $\mathrm{C}$ berakibat pada penurunan keanekaragaman fitoplankton dari 1,68; 1,63 
hingga 1,52; penurunan keseragaman dari 0,$89 ; 0,84$ hingga 0,81 ; serta peningkatan dominansi dari 0,$21 ; 0,23$ hingga 0,28. Menurut Makmur et al. (2012), baku mutu oksigen terlarut untuk fitoplankton pada perairan sungai adalah $3 \mathrm{mg} / \mathrm{l}$, semakin rendah kadar oksigen terlarut dapat mengakibatkan perubahan struktur komunitas fitoplankton. Diperkuat dengan Peraturan Pemerintah Nomor 82 Tahun 2001 mengenai Pengelolaan Kualitas Air dan Pengendalian Pencemaran, bahwa air dengan oksigen terlarut dengan kisaran 0 - 3 mg/l termasuk golongan kelas 4 dimana air tersebut peruntukannya digunakan untuk mengairi, pertanaman dan atau peruntukan lain yang mempersyaratkan mutu air yang sama dengan kegunaan tersebut, sehingga tidak layak untuk beberapa keperluan termasuk untuk air minum dan budidaya.Oksigen terlarut dari Stasiun A hingga Stasiun C menurun diduga karena semakin banyaknya limbah yang terdapat pada sungai tersebut, sehingga dekomposer yang ada pada sungai tersebut memerlukan lebih banyak oksigen untuk menguraikan limbah organik yang ada, akibatnya metabolisme dan respirasi fitoplankton pada malam hari akan terganggu (Novotny danOlem, 2013).Menurut Bartram et al. (1996), pada dasarnya pencemaran organik yang terjadi pada suatu perairan menyebabkan gangguan keseimbangan kadar oksigen dan disertai dengan pencemaran patogen. Pertumbuhan, kematian dan dekomposisi limbah yang terjadi memengaruhi kadar oksigen terlarut didalam air. Selain itu perbedaan kadar oksigen terlarut dapat juga diakibatkan karena perbedaan kegiatan fotosintesis oleh fitoplankton, difusi oksigen dari udara, serta variabel lain yang memengaruhi perbedaan nilai oksigen terlarut tersebut.

Nilai pH yang diperoleh pada setiap stasiun relatif sama, yaitu 7. Nilai yang didapatkan tersebut termasuk kedalam nilai $\mathrm{pH}$ normal dan baik bagi fitoplankton dan proses ekologis yang ada pada suatu perairan, sehingga tidak terlalu berpengaruh terhadap komposisi dan kelimpahan fitoplankton. Menurut Effendi (2003), pH yang terlalu asam dan basa, kurang dari 6 atau lebih dari 8 akan menyebabkan penurunan keanekaragaman fitoplankton, kelimpahan total biomassa serta produktivitas yang tidak mengalami perubahan. Hal ini diperkuat olehThe EnvironmentalandProtection Agency (2001), bahwa kisaran $\mathrm{pH}$ yang paling sering ditemui adalah 6.5-8.0. Di perairan dengan padatan terlarut rendah, memiliki kapasitas penyangga yang rendah (misal resistansi internal rendah terhadap perubahan $\mathrm{pH}$ ). $\mathrm{PH}$ ekstrim dapat memengaruhi palatabilitas air namun efek korosif dari sistem distribusi ini merupakan masalah yang lebih mendesak. Kisaran pH cocok untuk perikanan berkisar antara 5,0-9,0, meski 6,5-8,5 lebih baik.

Hasil pengukuran nitrat pada minggu pertama berksiar antara 2,417 - 3,425 mg/l. pada minggu kedua nitrat berkisar antara 3,728 - 5,521 mg/l, sedangkan pada minggu ketiga, nitrat 3,279 - 4,693 mg/l. Nilai nitrat rata-rata paling rendah berada pada stasiun $\mathrm{A}$, dengan nilai rata-rata $3,6 \mathrm{mg} / \mathrm{l}$,sedangkan nilai nitrat rata-rata paling tinggi berada pada stasiun C, dengan nilai rata-rata 4,2 mg/l.Berdasarkan hasil tersebut, kadar nitrat yang semakin meningkat yaitu dari 3,6; 3,8 hingga 4,2 menyebabkan perubahan struktur komunitas fitoplankton seperti penurunan keanekaragaman fitoplankton dari 1,68; 1,63 hingga 1,52; penurunan keseragaman dari 0,89; 0,84 hingga 0,81; serta peningkatan dominansi dari 0,21; 0,23 hingga 0,28. Kadar nitrat yang diperoleh pada setiap stasiun di Sungai Lanangan masih jauh di bawah ambang batas baku mutu lingkungan yang ditetapkan dalam Peraturan Pemerintah Nomor 82 Tahun 2001 tentang Pengelolaan Kualitas Air dan Pengendalian Pencemaran Air, yaitu $10 \mathrm{mg} / \mathrm{l}$ untuk air pada badan air golongan II. Akan tetapi menurut Chu dalam Patty et al. (2015), menyatakan bahwa kandungan nitrat dalam perairan yang melebihi $3,5 \mathrm{mg} / \mathrm{l}$ akan membahayakan perairan dan menyebabkan terjadinya eutrofikasi. Nitrat yang ada pada Stasiun A diduga berasal dari penggunaan pupuk dan pestisida yang digunakan di persawahan, karena memang Stasiun A dekat dengan persawahan. Sedangkan untuk stasiun dua dan tiga kadar nitrat yang banyak diduga karena banyaknya limbah organik dari kegiatan industri, peternakan serta limbah domestik lainnya. Menurut Susatyo et al. (2014), kadar nitratstasiun A yang dekat dengan persawahandapat dipengaruhi oleh penggunaan pupuk dan insektisida dimana banyak kandungan nitrogen di dalamnya. Kadar nitrat di perairan biasanya tidak terlalu banyak, karena sifatnya yang tidak stabil dan adanya penyerapan nitrat yang tinggi oleh makrofita maupun tumbuhan air lainnya seperti makroalga dan fitoplankton. Diperkuat oleh Sutriadi dan Sukristiyonubowo (2013), bahwa selain digunakan untuk makrofita dan tumbuhan air lainnya, nitrat dalam perairan juga diserap oleh tanah. Sehingga kadar nitrat dalam perairan tidak terlalu banyak.

Hasil pengukuran fosfat pada minggu pertama berksiar antara 0,299 - 0,538 mg/l. pada minggu kedua fosfat berkisar antara 0,876-2,677 mg/lsedangkan pada minggu ketiga, fosfat 0,452 - 0,754 mg/l. Nilai fosfat rata-rata paling rendah berada pada stasiun $\mathrm{C}$, dengan nilai rata-rata $0,6 \mathrm{mg} / \mathrm{l}$ sedangkan nilai fosfat rata-rata paling tinggi berada pada stasiun $\mathrm{B}$, dengan nilai rata-rata $1,3 \mathrm{mg} / \mathrm{l}$.Berdasarkan hasil tersebut, kandungan fosfat stasiun $\mathrm{A}$ hingga $\mathrm{C}$ yaitu 0,7 $\mathrm{mg} / \mathrm{l}, 1,3 \mathrm{mg} / \mathrm{l}$ hingga $0,6 \mathrm{mg} / \mathrm{l}$ berpengaruh pada kelimpahan fitoplankton, dimana semakin tinggi fosfat maka kelimpahan fitoplankton juga meningkat, sesuai dengan kelimpahan stasiun A hingga C yaitu $5334 \mathrm{mg} / \mathrm{l}, 5967 \mathrm{mg} / 1$ hingga $4432 \mathrm{mg} / \mathrm{l}$. Kandungan fosfat yang diperoleh pada setiap stasiun di Sungai Lanangan sangat tinggi dan telah melebihi ambang batas baku mutu lingkungan yang telah ditetapkan dalam Peraturan Pemerintah Nomor 82 Tahun 2001 tentang Pengelolaan Kualitas Air dan Pengendalian Pencemaran Air, yaitu sebesar 0,2 mg/l untuk air badan air golongan II. Diperkuat oleh EPA (2002) dan Ketchum (1969) dalam Patty et al. (2015), bahwa nilai fosfat <0,048 mg/l tergolong rendah, antara 0,048-0,096 mg/l tergolong sedang, dan >0,096 mg/l tergolong tinggi. sedangkan nilai fosfat sebesar 2,8 ug.at/l atau setara dengan $0,087 \mathrm{mg} / \mathrm{l}$ ditetapkan sebagai batas atas pada air yang tidak tercemar. Sama halnya dengan nitrat, fosfat juga dibutuhkan dalam kehidupan fitoplankton, meskipun dalam kenyataannya fosfat yang tinggi tidak menyebabkan gangguan kesehatan bagi organisme, akan tetapi ketika terjadi blooming fitoplankton dapat membahayakan perairan tersebut. Menurut Susatyo et al. (2014), bahwa fosfat berfungsi dalam sistem genetis, penyimpan dan transfer energi di dalam sel mahluk hidup khususnya fitoplankton. Diperkuat pula oleh Makmur et al. (2012), bahwa nilai $0,5 \mathrm{mg} / \mathrm{l}$ merupakan baku mutu fosfat dalam perairan sungai, apabila melebihi batas tersebut dapat mengakibatkan terjadinya peristiwa blooming fitoplankton. 
Perbedaan nilai fosfat yang ada pada Sungai Lanangan diduga disebabkan oleh beberapa hal, diantaranya adalah limbah organik yang banyak mengandung fosfat, pengadukan sedimen, daur biogeokimia dan lainnya. Hal ini diperkuat oleh Susatyo et al. (2014), bahwa tingginya nilai fosfat di perairan dipengaruhi oleh beberapa hal, diantaranya adalah aktivitas manusia seperti pertanian, perikanan, industri, rumah tangga dan peternakan; masukan fosfat dari hulu sungai serta daur biogeokimia yang terjadi pada sungai tersebut.

\section{KESIMPULAN}

Berdasarkan hasil penelitian yang telah dilakukan pada sungai Lanangan, dapat disimpulkan bahwa:

1. Kelimpahan fitoplankton di Sungai Lanangan yaitu 15.750 ind/l dengankomposisiyang terdiri dari 6 kelas dan 11 genera, yaitu Bacillariophyceae (4 genera), Cyanophyceae (2 genera), Chrysophyceae (1 genus), Ulvophyceae (2 genera), Zygnematophyceae (1 genus) dan Chlorophyceae (1 genus).

2.Kualitas air Sungai Lanangan dilihat dari indeks keanekaragaman fitoplankton Sungai Lanangan rata-rata adalah 1,52 - 1,68 yang termasuk dalam kategori tercemar ringan hingga sedang.

\section{UCAPAN TERIMA KASIH}

Penulis mengucapkan terima kasih kepada tim penguji dan panitia, Dr. Ir. Suradi Wijaya Saputra, MS, Oktavianto Eko Jati, S.Pi, M.Si dan Arif Rahman, S.Pi, M.Si yang telah berkenan memberikan arahan, bimbingan, kritik dan saran dalam penyusunan jurnal ini; kepada Koordinator Satker PBIAT Janti, Sartono, SP dan para stafnya yang telah membimbing peneliti di lapangan; serta kepada Setiaji Nugroho, S.Pi, Muchtar Yulianto, S.Pi dan Oki Trian Nugraha, S.Pi yang telah berkenan membantu peneliti di lapangan.

\section{DAFTAR PUSTAKA}

Adinugroho, M., Subiyanto, Haeruddin. 2014. Komposisi dan Distribusi Plankton di Perairan Teluk Semarang. Jurnal Saintifika. $16(2): 39-48$.

Anwar, Asni. 2014. Studi Kelimpahan dan Sebaran Phytoplankton Secara Horizontal (Kasus Sungai Kuri Lompo Kabupaten Maros). Jurnal Ilmu Perikanan. 3(2) : 280-286.

Ardiansyah, K. 2017. Hubungan Nitrat dan Fosfat terhadap Kelimpahan Fitoplankton di Perairan Pulau Anak Krakatau.[Skripsi]. Universitas Lampung, Bandar Lampung. $39 \mathrm{hlm}$.

Arikunto, S. 2006. Prosedur Penelitian Suatu Pendekatan Praktik. Jakarta: Rineka Cipta. 413 hlm.

Bartram, J., Ballance, R., Meybeck, M., Kuusisto, E., Mäkelä, A., dan Malkki, E. 1996. Water Quality. Water Quality Monitoring -A Practical Guide to the Design and Implementation of Freshwater Quality Studies and Monitoring Programmes. Penerbit : E\&FN Spon. 366 hlm.

Budiasih, R., Supriharyono, \& Muskananfola, M. R. (2015). Analisis Kandungan Bahan Organik, Nitrat, Fosfat pada Sedimen di Kawasan Mangrove Jenis Rhizophora dan Avicennia di Desa Timbulsloko, DEMAK. Diponegoro Journal of Maquares. 4(3), 66-75.

Cokrowati, N., S. Amir, Z. Abidin, B. D. H. Setyono dan A. A. Damayanti. 2014. Kelimpahan dan komposisi fitoplankton di perairan Teluk Kodek Pemenang Lombok Utara. Universitas Mataram. (1): 21-26.

Durocher, G. Y., A. P. Allen, M. Cellamare, M. Dossena, K. J. Gaston, M. Leitao, J. M. Montoya, D. C. Reuman, G. Woodward dan M. Trimmer. 2015. Five Years of Experimental Warming Increases the Biodiversity and Productivity of Phytoplankton. PloS. Biology. 13(12) : 1-22.

Effendi, H. 2003. Telaah Kualitas Air bagi Pengelolaan Sumber Daya dan Lingkungan Perairan. Kanisius. Yogyakarta. $258 \mathrm{hlm}$.

Handoko, Yusuf, M., \& Wulandari, S. Y. (2013). Sebaran Nitrat Dan Fosfat Dalam Kaitannya Dengan Kelimpahan Fitoplankton Di Kepulauan Karimunjawa. Buletin Oseanografi Marina. 2(4) 48-53.

Haq, N. F. A., Laili, S., \& Syauqi, A. (2015). Uji Kualitas Perairan dan Pengaruhnya terhadap Indeks Keanekaragaman Makrofauna di DAS Janjang Madura. BIOSAINTROPIS (BIOSCIENCE-TROPIC). 1(1).

Kamilah, F., Rachmadiarti, F., \& Indah, N. K. (2014). Keanekaragaman Plankton yang Toleran terhadap Kondisi Perairan Tercemar. LenteraBio.3(3). 226-231.

Khasanah, R. I., Sartimbul, A., dan Herawati, E. Y. (2013). Kelimpahan dan Keanekaragaman Plankton di Perairan Selat Bali (Plankton Abundance and Diversity in the Bali Strait). Ilmu Kelautan: Indonesian Journal of Marine Science., 18(4) 193-202.

Makmur, M., Kusnoputranto, H., Moersidik, S. S., \& Wisnubroto, D. S. 2012. Pengaruh Limbah Organik dan Rasio N/P terhadap Kelimpahan Fitoplankton di Kawasan Budidaya Kerang Hijau Cilincing. Journal of Waste Management Technology. 15(2) : 51-64.

Novotny V. dan Olem H. 2013. Water Quality: Prevention, Identification, and Management of Diffuse Pollution. Penerbit: Van Nostrand Reinhold, New York. $1054 \mathrm{hlm}$.

Nybakken, J.W. 1992. Biologi Laut. Gramedia Pustaka Utama, Jakarta. 459 hlm. 
Odum, E. P. 1993. Dasar-Dasar Ekologi. Edisi Ketiga (Diterjemahkan Oleh T. Samingan. Gajah Mada University. Yogyakarta. $697 \mathrm{hlm}$.

Patty, S. I., H. Arfah dan M. S, Abdul. 2015. Zat Hara (Fosfat, Nitrat), Oksigen Terlarut dan pH Kaitannya dengan Kesuburan di Perairan Jikumerasa, Pulau Buru. Jurnal Pesisir dan Laut Tropis. 1(1) : 43-50.

Rahmawati, I., I. B. Hendrarto dan P. W. Purnomo. 2014. Fluktuasi Bahan Organik dan Sebaran Nutrien serta Kelimpahan Fitoplankton dan Klorofil-a di Muara Sungai Sayung, Demak. Jurnal Manajemen Sumberdaya Perairan. 3(1) : 27-36.

Rigitta, T. M. A., L. Maslukah, M. Yusuf. 2015. Sebaran Fosfat dan Nitrat di Perairan Morodemak, Kabupaten Demak. Jurnal Oseanografi. 4(2) : 415-422.

Rudiyanti, S. (2011). Kualitas Perairan Sungai Banger Pekalongan Berdasarkan Indikator Biologis. SAINTEK PERIKANAN : Indonesian Journal of Fisheries Science and Technology, 4(2) : 46-52.

Sachlan, M. 1982. Planktonologi. Fakultas Oeternakan dan Perikanan Universitas Diponegoro, Semarang. 117 hlm.

Sagala, E. P. (2012). Komparasi Indeks Keanekaragaman dan Indeks Saprobik Plankton untuk menilai Kualitas Perairan Danau Toba Provinsi Sumatera Utara. In Prosiding Seminar Nasional Limnologi VI Tahun 2012. 220 233.

Soegianto, Agoes. 2010. Ekologi Perairan Tawar. Airlangga University Press. 75 hlm.

Sulardiono, B., Sahala H., Ali D.. 2015. Buku Ajar Planktonologi. LPPMP Universitas Diponegoro. Semarang. 120 hlm.

Sumartini, Susi. 2013. Kualitas Perairan Sungai Seketak Semarang berdasarkan Komposisi dan Kelimpahan Fitoplankton. [Skripsi]. Universitas Diponegoro. Semarang. 46 hlm.

Susatyo, A., Tanjung, S. D., \& Hendrarto, B. (2014). Distribusi serta kandungan nitrat dan fosfat di perairan danau rawa pening. Bioma. 3(1) : 27-41.

Sutriadi, M. T. dan Sukristiyonubowo. 2013. Pencemaran nitrat pada air Sungai Sub DAS Klakah , DAS Serayu di sistem pertanian sayuran dataran tinggi. Jurnal Tanah dan Iklim. 37(1) : 35-44.

The Environmenta dan Protection Agency. 2001. Parameters of water quality. Penerbit: Environmental Protection. 133 hlm.

Trisnastuti, Arum Asri. 2012. Kualitas Limbah Cair Industri Mie Soun dan Pengaruhnya terhadap Pertumbuhan, Tingkat Kelangsungan Hidup dan Struktur Mikroanatomi Insang Ikan Nila (Oreochromisniloticus). [Skripsi]. Universitas Sebelas Maret, Surakarta. $60 \mathrm{hlm}$.

Usman, M. S., J. D. Kusen, J. R. T. S. L. Rimper. 2013. Struktur Komunitas Plankton di Perairan Pulau Bangka Kabupaten Minahasa Utara. Jurnal Pesisir dan Laut Tropis. 2(1) : 51-57.

Wibowo, H. P. E., T. Purnomo dan R. Ambarwati. 2014. Kualitas Perairan Sungai Bengawan Solo di Wilayah Kabupaten Bojonegoro berdasarkan Indeks Keanekaragaman Plankton. Universitas Negeri Surabaya. 3(3) : 209215.

Widyaningsih, R., C. H. Muryani dan D. Endarto. 2013. Kajian Kualitas Air Tanah Dangkal di Area Industri Tepung Aren Desa Daleman, Kecamatan Tulung, Kabupaken Klaten Tahun 2012. 1590(1) : 1-10.

Yuliana, E. M. A., Enang H., Niken T. M. P.. 2015. Hubungan antara Kelimpahan Fitoplankton dengan Parameter Fisik-Kimiawi Perairan di Teluk Jakarta. Jurnal Aquatika. 3(2) : 169-179. 